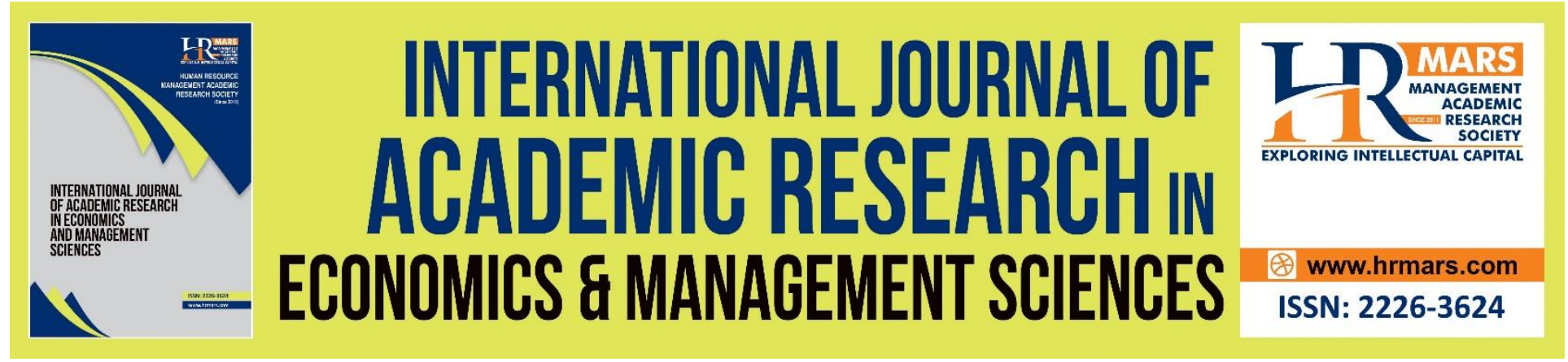

\title{
Technology Adoption and Employee's Job Performance: An Empirical Investigation
}

Shathees Baskaran, Ho Sze Lay, Beh Sze Ming and Nomahaza Mahadi

To Link this Article: http://dx.doi.org/10.6007/IJAREMS/v9-i1/7443

DOI: 10.6007/IJAREMS/v9-i1/7443

Received: 25 Jan 2020, Revised: 26 Feb 2020, Accepted: 20 Mar 2020

Published Online: 29 Apr 2020

In-Text Citation: (Baskaran et al., 2020)

To Cite this Article: Baskaran, S., Lay, H. S., Ming, B. S., \& Mahadi, N. (2020). Technology Adoption and Employee's Job Performance: An Empirical Investigation. International Journal of Academic Research in Economics and Managment and Sciences, 9(1), 78-105.

\section{Copyright: (C) 2020 The Author(s)}

Published by Human Resource Management Academic Research Society (www.hrmars.com)

This article is published under the Creative Commons Attribution (CC BY 4.0) license. Anyone may reproduce, distribute, translate and create derivative works of this article (for both commercial and non-commercial purposes), subject to full attribution to the original publication and authors. The full terms of this license may be seen at: http://creativecommons.org/licences/by/4.0/legalcode

Vol. 9, No. 1, 2020, Pg. 78 - 105

Full Terms \& Conditions of access and use can be found at http://hrmars.com/index.php/pages/detail/publication-ethics 


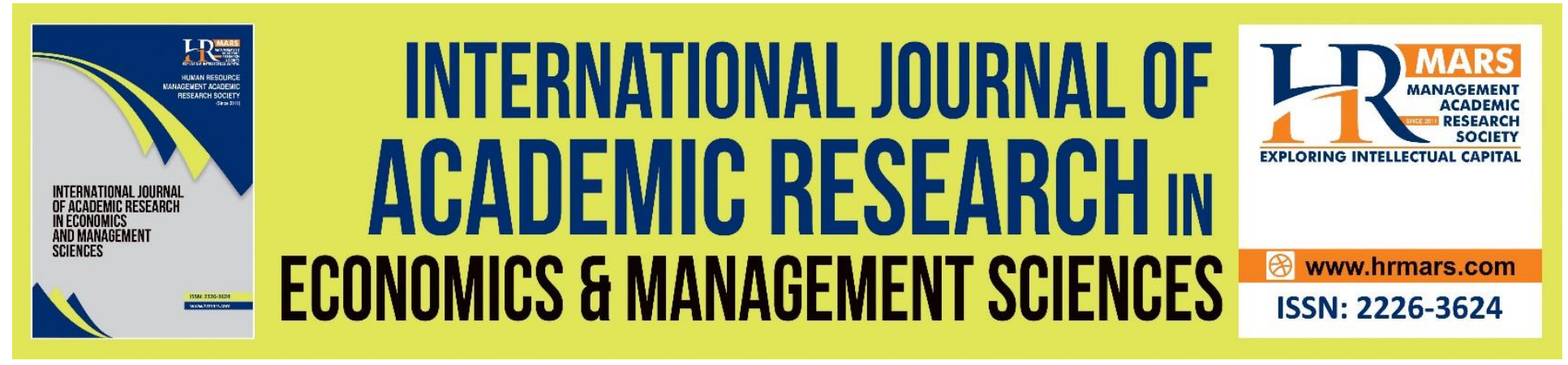

\title{
Technology Adoption and Employee's Job Performance: An Empirical Investigation
}

\section{Shathees Baskaran, Ho Sze Lay, Beh Sze Ming and Nomahaza Mahadi}

Azman Hashim International Business School Universiti Teknologi Malaysia, Malaysia

Email: shathees@utm.my, szelay0809@gmail.com,bill_cc@hotmail.com, nomahaza.kl@utm.my

\begin{abstract}
Technology innovation has an important influence on employee's job performance where it helps to reduce human error, increase productivity, and increase the speed of communication. Many organizations are facing difficulties in choosing suitable technology adoption strategies with the hope to improve efficiency and enhance employee performance to be competitive in the market. Hence, the purpose of this research is to investigate the relationship between technology adoption drivers and employee job performance in the Malaysian Manufacturing Industry. Several dimensions for employee job performance were considered in this research namely job stress, motivation, and workload. In addition, the mediating effect of perceived job insecurity was also evaluated on the relationship between technology adoption and employee job performance. Employing a quantitative research method, data was collected from 370 respondents through a structured online survey questionnaire. The findings indicated that job satisfaction and motivation to be statistically significant while the workload was failed to be retained in the research. Additionally, there was no statistical evidence for the mediating effect of job insecurity in the research. It is envisaged that these findings will provide incremental insights into the existing body of knowledge while providing some directions to the organization in determining the right set of drivers inculcating technology adoption for improved job performance.
\end{abstract}

Keywords: Technology Adoption, Job Performance, Job Stress, Motivation, Workload, Perceived Job Insecurity.

\section{Introduction}

Technologies have been undergoing a drastic transformation over time, there is always new creations and innovation that appear in the market. Our life has been tied with technologies since our born, from the technologies and machines used in hospitals to the smartwatches on our hand, technologies have become one of the most essential things in our life. The reason for the high acceptance of technologies in an organization is because technology is one of the most 
significant elements that related to effective operations management in an organization (Ahmad, 2014). According to Odeh (2019), business transparency and efficiency is found to increase when there is a use of technology in the organization. With the advance and dynamic growth of technologies, how fast the consumers are accepting these technologies depends on a number of factors such as availability of technology, convenience, consumers' adoption of new technologies (Meuter, Ostrom, Roundtree, \& Bitner, 2000). As a result, this research will present the study of technology acceptance models and theories leading to the effects on employee's performance. In this study, we will focus on research based on the manufacturing industry. The reason for choosing manufacturing industry as our main focus is that manufacturing industry is heavily attached to technologies, for example, a competitive medicine manufacturing industry is one of the manufacturers who invented some new advance technologies that can help increase the efficiency of production and decrease the total production cost, the company will become the leader in the medical manufacturing industry. As a result, the manufacturing industry will be the best choice for understanding the technology adoption model.

Technology has become extremely important to every job in the work environment, it helps to reduce human errors, increase efficiency, and increase the speed of communication. Many of the organization are facing issue or problem on selecting the right technology adoption strategies to adopt in the organization as they are concerned on how the technology can help improve efficiency and productivity, as well as enhancing the employee performance, in order to be competitive ahead of others. From the employee perspective, they are concerned on would their job being replaced by technology advancement. In the past, most of the public perceived that technology will take over the human job in the future, hence it creates a negative perception to the public that the purpose of technology creation is to replace human jobs. While on the other hand, some people believed that, the existence of technology is to lead the human to another level that life becomes more efficient and convenient.

The major problems faced by the employee in a manufacturing company are the adoption of technology creating job stress to the worker, as they perceived that technology will take over their current job. Other than that, the process of adopting new technology in an organization will create many problems for worker's day-to-day processes, as they have to accommodate and force to use new technology in their task, the learning cost of new technology will be much higher at the beginning.

Based on past research, there is very limited research related to technology adoption in an organization affecting the employee's job performance and leads to job insecurity. However, some researchers notice there is a relationship between these variables. As mentioned by Hampel and Martinsons (2009), adopting new technology will change the organizational policies and strategies. In most of the organization, the challenges they faced is generated by the advanced technology, competition in the industry, improving employee efficiency, new leadership, and management (Madsen et al., 2005). Much research has shown that employee behaviors and attitudes need to be developed in order to enhance organizational performance (Bernerth, 2004). It is important to investigate the adoption of technology by the employee within the organizations. This is because if there is no acceptance among the employees, the desired outcome or benefit of technology adaptation would not be realized and the organization may have to evacuate technology (Talukder, 2012). Most of the time, people tend to resist or refuse new changes unless they can be convinced that the changes can benefit them (Ajzen, 
1991). Therefore, the organization needs to motivate the employees to accept the changes and adopt the new technology, where the organization should give either intrinsic or extrinsic motivation to employees for better performance (Dauda \& Akingbade, 2011).

According to Imran, Maqbool, and Shafique (2014), the adoption of new technology will enhance employee performance when they use technology for the benefit of the organization with ethical value. He further explained that the advancement of technology helps to reduce the workload of the employees and human effort. It is clear that advanced technology helps to reduce manpower in the manufacturing industry but there is some problem associated with advanced technology. First, technostress is one of the factors that will reduce the employee's performance and it will contribute a high level of job insecurity. Technostress occurs when an employee is lacking the need for skills and competencies to performing the task. It can be defined as an individual adaptation of the reaction exceed the psychological and physical demands (Park \& Im, 2012). Other than that, technostress may lead to job insecurity where the employee is fear or anxious about losing their job or being replaced by the new adopt technology (Ho-Jin, \& Cho, 2016). Thus, the organization needs to study what are the most suitable technology need to adopt before implementing it.

In discussing the significance of this study, it is envisaged that the manufacturing industry could gain some insights to understand the behavior of the employee when adopting new technology into the workplace. In addition, the manufacturing industry will be able to understand how to utilize the technology acceptance model to evaluate the effects on the workplace by using perceived usefulness and perceived ease of use to measure the relationship of technology affects employee's job performance, job stress, workload, and work motivation. Other than that, the study also helps organizations to understand whether it is worthwhile to adopt new technology in the workplace without increasing the stress levels of workers, decrease the workload, and encourage employees to work more efficiently.

The research aimed to investigate the relationship between technologies adoption strategies in the Malaysian manufacturing industry that affecting the employee's job performance. In this research, the researcher has chosen a number of factors that can affect job performance such as stress, motivation, and workload. The mediating effect for this research will be job insecurity that acts as a factor that influences the motivation of the employee in the organization and employee job insecurity will be influenced by the technology adoption in the organization. Thus, this research aims to achieve the following objective: i. determine the relationship between technologies adoption strategies and employee's job performances (and related dimensions) and ii. determine the mediating effect of perceived job insecurity on the relationship between technologies adoption and employee's job performance.

\section{Literature Review}

Technology and Workplace

In recent research, most of the research emphasis on organizations should motivate employees to increase the adoption rate of technology in the organization (Talukder, 2012). Besides, based on Imran et al. (2014), the employee's performance will be influenced by technological advancement. Most of the studies have repeatedly proved that appropriate technology adoption will have a positive relationship with the employee's performance. However, the organization should motive employees by providing training and skill development activities, so that 
employees can rapidly acquire new knowledge and competencies that require by advanced technology. Some researchers also mentioned that the implementation of advanced technology within the organization will create technostress to the organization members. (Ho-Jin, \& Cho, 2016). Technostress occurs when the employee has a low level of skill and knowledge to perform the task which will have a significant influence on job performance and productivity, as well as role stress. Through the prior research, the cause of technostress will directly influence the achievement of the organization (Im \& Han, 2013).

Apart from that, there is some contrast to the employee workload after adopting new technology. Most of the researches mentioned that workload could be reduced through the adoption of advanced technology where the employee can perform their task without any hurdle. However, there is some researchers believe that technology will make individuals carry out more tasks within a short period as their superior will require them to provide more necessary data. Besides, all these factors will lead an individual to experience a high level of job insecurity where they are anxious about their job will be replaced by technology. According to the world economic forum, more than a million jobs will be affected by the advanced technology in the next 5 to 10 years. The research is then proving that nearly half (49\%) of the people are believing that their job is insecure due to the emerging of new technology. Thus, this research will further investigate the relationship between technology adoption and employee performance as well as the mediating factor of perceived job insecurity.

\section{Technology Adoption}

Both individuals and organizations tend to adopt new technology when there are some potential benefits that could increase their market competitiveness. Technology adoption is defined as the choice or decision, by individual or organization, to acquire and implement a new innovation technology. In the growing technology needs environment and increasing failures of technology adoption in the organization, a reliable behavior predicting tool has become an interesting topic for many companies. The adoption of technology not only depend on organizational strategies, policies, and action, but it also relies on the employee's attitude. Nevertheless, technology adoption requires strong managerial efforts and commitments in the organization (Achieng \& Jagero, 2014). Hence, organizations require to provide sufficient facilitating conditions such as technology and resource support which would eventually influence them on using new technology. Generally, people tend to resists or refuse to adopt the changes, unless they can be convinced that the changes are beneficial to them. However, many studies are failed to carry out reliable behavior measures that help to explain technology acceptance or rejection (Davis, 1989). Davis (1989) proposes that user motivation can be explained by 3 factors: Perceived Usefulness (PU), Perceived Ease of Use (PEU), and attitude toward using the technology. In his proposal, attitude-behavior towards technology is the main factor that determines whether the user will actually adopt or reject technology.

In addition, the important factors that affect the attitude are perceived usefulness and perceived ease of use (Swanson, 1982). Perceived usefulness is defined as user perceived that the function of the adopting technology helps to improve or enhance their job performance (Schultz \& Slevin, 1975). Perceived ease of use is defined as the user-perceived learning for using particular technology shall be effortless (Tornatzky \& Klein, 1982). The success of the technology 
acceptance model has become a very popular study cited in most of the research that studies the user acceptance of technology (Lee, Kozar \& Larsen, 2003). On the other hand, some researchers claim that the technology acceptance model is much easy and quick research, so it does not give enough attention to the real problem of technology acceptance (Lee, Kozar \& Larsen, 2003).

Although technology acceptance model has been very popular among researchers, there is a limitation that happened to the model, as researchers pointed out that self-reported data is a subjective measure, so it is unreliable in measuring the actual use of technology (Legris, Ingham \& Collerette, 2013, Yousafzai, Foxall, \& Pallister 2007). On the side note, in real-life cases, the majority of organizations usually have little choices of alternative technology available for users to test out (Lee at al., 2003). Moreover, Bagozzi (2007) argued that the technology acceptance model may not have the ability to represent the actual usage, because the time between intention and adoption is full of uncertainties that may influence an individual's decision on adopting a technology.

\section{Employee Job Performance}

Based on the Motowidlo, Borman, and Schmidt (1997), job performance can be defined as the total expected quality and value in a particular job from an employee's behaviors carried over a standard period of time. There are two distinct dimensions of work behaviors in job performance which are contextual (citizenship) performance and task performance (Kahya, 2009). Contextual performance is described as the employee's effort that is not directly related to their main job function but their efforts are important as they support the organizational, social, and psychological environment that serves as the critical catalyst for job activities and processes (Werner, 2000). Whereas, the task performance is defined as the employee perform the job activities are formally recognized as part of their jobs and the activities that will be contributed to the organization (Borman \& Motowidlo, 1993). According to Witt, Kacmar, Carlson, and Zivnuska (2002), contextual performance produces a competitive advantage for organizations than task performance.

Besides, job performance can also be defined as the individual behaviors that performed activities or tasks to achieve the organization's goal and objective (Motowidlo, Borman, \& Schmidt, 1997). It is an important factor that will be affecting the profitability of the organization where inefficient job performance will destruct the overall organization productivity, profitability, and effectiveness. Other than that, Employee' job performance is significant for the organization as their performance and contribution will lead the business toward success, as well as achieve competitive advantages. Performances are also important for individuals as the accomplishment of a job and performing tasks at a high level can be a source of satisfaction (Muchhal, 2014). The employee who is low performance and fails to achieve organizational goals might be experienced as dissatisfaction or personal failure. There might be exceptions for those high performers as they will have a better career opportunity and get promoted more easily within the organization than the low performers (Van Scotter, Motowidlo, \& Cross, 1996).

The employee's job performance can be affected by numerous factors in their working environment. Based on some researchers and practitioners, performances of employees at the workplace may affect by various factors which can be the change of job function, exclusive nature, systematic technology development, or weakening in job satisfaction (Saeed, Mussawar, 
Lodhi, Iqbal, Nayab, \& Yaseen, 2013). There are certain factors that individually and collectively affect employees either enhance or lower their job performance.

\section{Job Stress}

Stress is a state of physical, mental, or emotional strain or tension resulting from adverse or a condition of feeling experienced by an individual perceived demand to exceed personal endurance. The term job stress can be described as a group of harmful emotional and physical responses that occur when the requirements of the job go beyond their capabilities, resources or needs of the employees (French, 1975). The researcher supports the idea that the higher the imbalance between the job demands and the personal capabilities and abilities, the higher the job stress experiences by the individual (Jamal, 2005), which simultaneously fails to satisfy the top management. In other words, job stress can be an awareness indicated by conflict, ambiguity, and overload that occur from the work environment and the characteristic of individuals.

According to Mizuno, Yamada, Ishii, and Tanaka (2006), job stress has been known as a universal social problem which combines the two factors of disrupt employees psychologically and physically, as well as affect their health (Conway, Campanini, Sartori, Dotti, \& Costa, 2008). There are much research has been conducted on the effect of job stress in terms of medical perspectives such as sleep disorder, heart disease, gastroenteritis, and others that will lower employee job performance, increase the rate of employee absences, and also job displacement (Poissonnet \& Veron, 2000). However, based on the Japanese management rules, the effectiveness of the organization depends on the top management or the leader's ability to drive the power of stress in themselves and employees, and transform the stress into energy for success.

Based on the researches, job stress can be categorized into two types (Rizwan, Waseem, \& Bukhari, 2014). The first type is positive stress, where the stress is beneficial when the employee feel challenged as the stress will be an opportunity for the employee to increase their job performance and shift the stress into energy to achieve their goal. According to Zafar, Ali, Hameed, Ilyas, and Younas (2015), setting a reasonable level of stress on employees can help to enhance the employee's performance. This is because the stress will motivate employees to work hardly and effectively, in order to achieve the organization's goals. Thus, there is a positive relationship between job performance and job stress. On the other hand, the second type is negative stress or distress, when the degree of stress exceeds the limit of an individual, which will generally reduce their performances. Some of the researches believed that job stress places some negative influences where it can decrease productivity, undermine creativity, and lower the quality of the job (Hsieh et al., 2004). Job stress can arise from the three aspects which are organizational, environmental and individual factors. There are many factors that can create job stress which is intrinsic to job, role and position in the organization, career development, relationship at work, change of organizational structure and climate, new technological adoption, change of job function and many others factors that can be led to influence the employee's job performance.

\section{Motivation}

Motivation is known as an internal process which directs individual to behave in a particular way. It can be defined as the desire or willingness of an individual to perform some task or the ability 
to satisfy some needs (DeCenzo \& Robbins, 1996). Other than that, motivation can be also defined as the energy or force that moves employees forward to performing a certain activity or task. This motivation will help to strengthen the willingness of employees to work and also improve the organization's effectiveness and competitive advantages (Parashar, 2016). According to Muda, Rafiki, and Harahap (2014), the motivated employees relate to the attitude of self-fulfillment, self-satisfaction, and self-commitment that are expected to perform better job quality and are more persistent to achieve desired goals which will extensively competitive advantage and materialize efficiencies. Besides, motivation will increase employee job involvement by making the task more interesting and meaningful, and it helps to enhance employee's productivity and improve their job performance (Ekerman, 2006).

The motivation of employees is one of the most significant and essential factors for the achievement of employees which will eventually accomplish or achieve the organization's goals and targets. One of the major problems facing the organization is motivation because it is an important factor in order to retain or attract employees inside the company. It also acts as a connection between the employees and the organization target which will lead the employees to be more innovative and creative to move them to go beyond the limitation of tasks (Parashar, 2016). George et al (2002) are further strengthening the relationship between job performances and motivation as he stated that motivation is a factor that contributes to the performances.

Apart from that, motivation can be classified into two primary types which are intrinsic motivation and extrinsic motivation. Intrinsic motivation is driven by the internal force within an individual, which refers to employees to get satisfaction and enjoyment from performing a work (Lin, 2007). It can be further explained that intrinsic motivation is the performance of a task for its own sake or satisfaction rather than another outcome. Whereas extrinsic motivation is driven by the external force to the individual, which can be described as an individual perform an action or certain task is affected by the external factor such as rewards and benefits (Lin, 2007). Many researchers and theories have proven that intrinsic motivation is more effective than the extrinsic motivation in motivating the employees. (Giancola, 2014). However, there is an argument on the researcher which mentions extrinsic motivation is more effective as the employees receive rewards when putting in more effort to accomplish their work, job security, and get promotions (Nasri \& Charfeddine, 2012). Therefore, it can be concluded that both motivations have their pros and cons and it would be better if the organization motivate employees by considering the internal and external factors.

\section{Workload}

The workload can be defined as the amount of work or task, which the employee is responsible to complete on the given task (Ali, Raheem, Nawaz, \& Imamuddin, 2014). The amount of work will create pressure or stress to the employees when it has exceeded the employee's capacity level. The researcher mentioned that the workload is perceived as a very critical issue or problem among the employee who is working in the manufacturing industry (Ibrahim, 2013). As mentioned by Ibrahim (2013), stress will occur when an increased workload on an individual which can affect their job performance and the achievement of the organization. The factor refers to the level of stress that has been experienced by the employees due to the conception that they are not able to adapt to the amount of work that has been assigned to them (Idris, 2011). 
The workload can be categorized into two types which are role overload and role lower load. Role overload is defined as when the employees are expected to do beyond the limit on the availability of time, resources, ability, and capability, where their direct employer or top management is giving a very high expectation on their work (Ammar, 2016). According to Conley and Woosley (2000), role overload can be quantitative and qualitative, where quantitative takes place when the employees have a high amount of work to complete or the period provided is too short to complete the task. Whereas, qualitative happen when the employee has insufficient ability to perform the task. On the other hand, role lower load is described as when the duties or workload is less than the level of employee capabilities, the individual may feel bored or afraid and fear. They may feel their job is insecure as their presence is a lack of importance which will affect their job performance. Apart from that, the workload may increase when there is technological change, restructuring of the organization, change of job functions, or workforce adjustment.

\section{Perceived Job Insecurity}

Perceived job insecurity can be described as an individual's job is perceiving threaten where they are fearful of losing a respective job (Hellgren \& Sverke, 2003; Awan \& Salam, 2014). Job insecurity will lead to an individual unpredictability and uncertainty on their employment which will generally create stress and impact on their health, behavior, and attitude (Sverke, \& Goslinga, 2003). The performance of an employee can be affected drastically due to the insecurity of the job (Yusoff, Mat \& Zainol, 2017). According to Campbell and Sengenberger (1994), job insecurity can determine the well-being of an individual from various perspectives which can be further explained that the lifestyle and health of an individual can be determined by the status of current job security.

There are many factors that may impact job security such as demographic, age, gender, qualification and experience. All these factors play an important role in creating individual job insecurity. Based on Elst et al. (2014), people in the age of 40s who have the responsibility to raise children and old age employees experience more job insecurity. Other than that socioeconomic status also one of the factors that impact job insecurity where an individual having a low education level and low status would have a high level of insecurity (Sverke, 2003). Many researchers have shown that job insecurity does not only look on the ability to lose a job but it may be viewed in other dimensions of the job such as short term laid off, benefits cut, growth, and promotion being cut off are defined as job insecurity (Klug, 2017).

According to Vieitez, Carcía, and Rodríguez's (2001) study, job insecurity seems to be influenced by the factor situational and personal characteristics. For those who have a low level of qualification and their occupation is related to automation, they would experience more intensely on the perception of technology as a threat to their job security. In other words, different levels of position or social status, age, qualification, experience or competence of employees who acquired to work with new technology will have to experience high job insecurity. Thus, the effects of technological change within the organization would give a positive relation to job insecurity.

Underpinning Theory: Technology Acceptance Model (TAM)

Technology Acceptance Model (TAM) was introduced by Fred Davis (1989) which is a theory that specifically tailored to predict the acceptance and use of technologies or information systems by 
individuals. Technology Acceptance Model is an extension of the Theory of Reasoned Action (TRA), however, it does not have the characteristic of subjective norms in the structure from TRA. Technology Acceptance Model is an information system theory that followed by information seekers or learners, who accept, inculcate, and utilize new technologies in their life. In the past studies, this Model is remained one of the most influential models and widely used by various research that explains an individual's technology acceptance behavior in a different type of technology (Surendran, 2012).

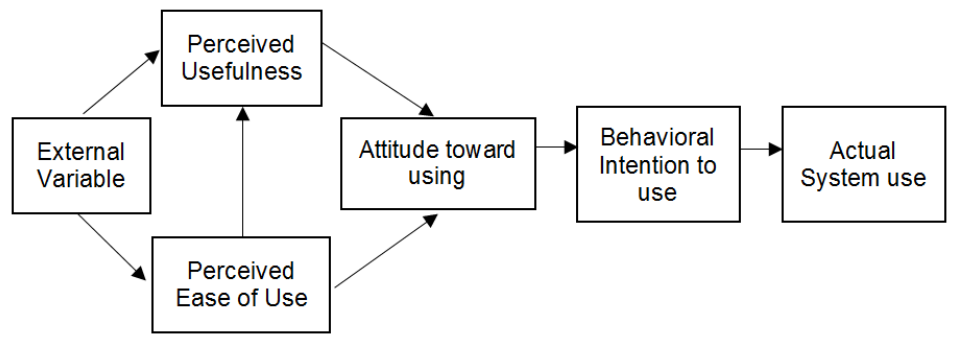

Figure 1 Technology Acceptance Model (TAM) (David et al, 1989)

In TAM, there are two main factors that determine the acceptance of the use of technology and user behavior, which are perceived usefulness (PU) and perceived ease of use (PEU). Perceived Usefulness is defined as the potential of user-perceived that certain systems or technologies will improve his/her daily task, which is seen as "performance expectancy" by Pantano and Pietro (2012). Perceived ease of use can be defined as the degree of which the potential of the user expects the targeted system to be useful and effortless (David, 1989), which is seen as "effort expectancy" (Kwon \& Wen, 2010). Based on Venkatesh and Bala (2008), TAM manages to consistently explain $40 \%$ of the variance in an individual's intention. Apart from that, TAM is concerned with the system characteristics that will influence the individual acceptance level.

The development of the Technology Acceptance Model passed through three main phases, which are adoption, validation, and extension (Han, 2003). The adoption phases are concerned with the parsimonious of TAM. The Validation phase can be divided into two main parts. The first part is to prove the psychometric characteristics of TAM's two main factors, perceived usefulness (PU) and perceived ease of use (PEU). Whereas, the second part of the validation phase is to prove the relationship between TAM's constructs and external variables that affect perceived usefulness and perceived ease of use (Al-Aulamie, 2013). The extension phase is to extend the TAM by including external variables or moderating variables. Technology Acceptance Model is extensively used by many researchers in their study. Despite the growth of information usage, Technology Acceptance Model has proven that it can help to confirm the age, income level, education, and race are associated with the information and beliefs that can influence the attitude toward and use of skills that enhance access to information.

\section{Research Model and Hypotheses}

Based on the above finding, the proposed conceptual framework on the study indicates the possible relationship between technology adoption in an organization and employees' job 
performances among the manufacturing industry in Malaysia. Perceived job insecurity representing in the framework below it acts as a mediating effect on the relationship between both technology adoption and employees' job performance. There are three factors that contribute to employee's job performance which are job stress, motivation, and workload. Other than that, the conceptual framework below is to investigate how technology adoption in an organization plays a significant role in affecting employee's job performance in the Malaysian manufacturing industry as it may give a positive or negative impact on the organization. Based on the discussions above, the following hypotheses were formulated:

H1a There is a significant relationship between technology adoption and job stress. $\mathrm{H} 1 \mathrm{~b} \quad$ There is a significant relationship between technology adoption and motivation. $\mathrm{H} 1 \mathrm{c} \quad$ There is a significant relationship between technology adoption and workload. $\mathrm{H} 2 \quad$ The mediating effect of perceived job insecurity on the relationship between technology adoption and employee job performance.

In order to test these relationships, a theoretical framework as shown in Figure 2 was proposed in this study.

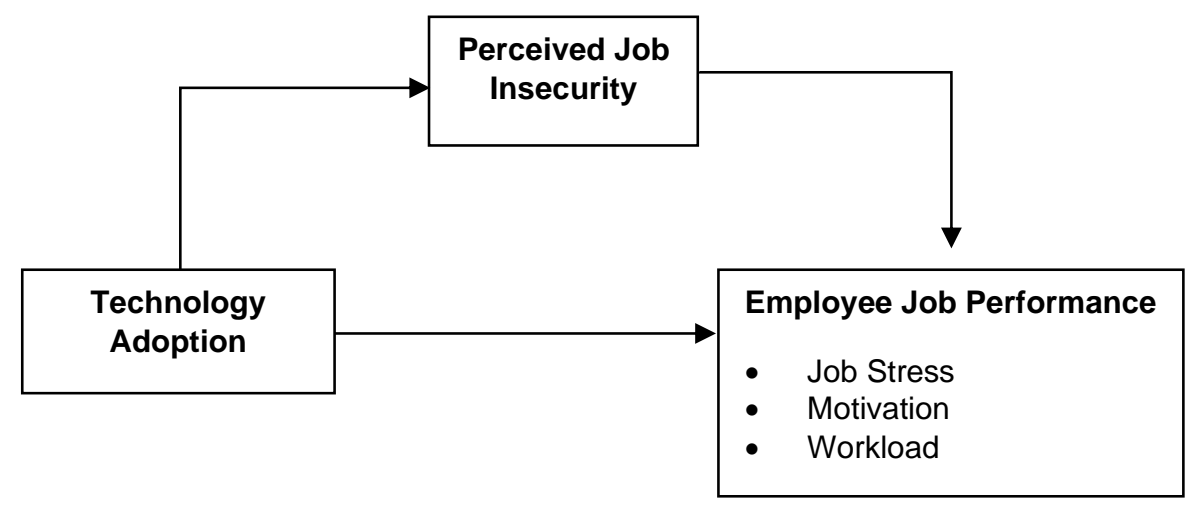

Figure 2 Research Model

\section{Methods}

Sample and Data Collection

This study proposes to employ a survey using a quantitative method to understand and test the accuracy of the theories in providing the relationship between technology adoption in an organization and employee's job performances. The data collection for this study is through survey questionnaires, by distributed to a large pool of respondents throughout the Malaysian manufacturing industry. In order to attain data effectively, these survey questionnaires use an internet survey as the platform because it saves time, cost-effective, and the ease of distributing the questionnaires to the respondents. The survey questionnaires are described in detail on the technology adoption in an organization and employee's job performance level among the Malaysian manufacturing industry, as well as the perceived job insecurity as the mediating factor. The employee's job performance level among the respondents will be tested and the survey question is based on the factors that affect job performance such as job stress, motivation, and workload. 
This research was mainly focused on the workers who are working in the Malaysian manufacturing industry that are from the age group of 18 to 60 years old. The Malaysian manufacturing industry employed more than 1 million people. Based on the Krejcie and Morgan (1970) sample size calculation, exceeding a maximum population size of 100,000 requires a minimum of 384 usable respondents. Therefore, for this study minimum sample size of 384 respondents is needed in order to obtain the reliable answer to the research question investigated and gather the necessary information to describe the characteristics of the entire population (Chuan, 2006). A simple random sampling method will be used for this research where the sample is choosing among a wide range of populations. The target audiences for this research are those who are working in the Malaysian manufacturing industry and everyone has the chance to being selected as a sample, it depends on the willingness of the respondent in participating this research.

The data collection procedure is a plan on how to access and gather information from the respondents. This research is focused on the quantitative method where all the data are collected through survey questionnaires. It will be analyzed using statistical software and tested against the hypothesis. In this research, primary data collection is mainly based on a quantitative research method where the information or data is collected through the online survey questionnaires. Whereas, the secondary information will be gathered through journals and articles.

Firstly, the questionnaire was designed based on the research variables which include the technology adoption in an organization as the independent variable, employees' job performance with three dimensions (Job stress, Motivation, and Workload) as the dependent variables, and perceived job insecurity as the mediating factors. Other than that, the questionnaires will also comprise the demographic profile of the respondents. The explanation of the purpose and significance of this study will be highlighted at the beginning of the questionnaires as this is to ensure that the respondents understand the research and have a clear mindset when filling the questionnaires. The distributed questionnaires are divided into four sections which are sections I, II, III and IV. For Section I, it is mainly contained on the general questions that relate to the personal information of the people who are working in Malaysia manufacturing industry and their background details such as age, gender, ethnicity, qualification, income level, years of service, job functions and levels of position in the respective organization. Whereas, for section II, it will purely be focusing on technology adoption in the organization that could be determined. In this section, the respondent will be asked on technology adoption provide by the organization to provide adequate support to the employees. For section III, it will comprise the employee's job performance such as job stress, motivation and workload that affecting by the technology adoption in the organization. The last section IV of the questionnaires will be the mediating factor of perceived job insecurity and to examine the job security level of the respondent in their organization. The survey questionnaires will be distributed or circulated to the target audience through internet platform and hardcopy distribution. The process of distributing the questionnaires and collection of data will be estimated to take a period of one to two months to complete. The data collected from the survey questionnaires will be analyzed using the Statistical Package for Social Sciences (SPSS) software. This SPSS software is used to summarize and analyze the collected data from the survey, as well as exploring the relationship between the responses to a different question. Besides, SPSS also well serve in calculating the 
correlation between the research variables and the mediators and transform the raw data into usable information which will address the research question and hypothesis

\section{Measures and Instrumentation}

Measures

The measurement used for this research is a nominal scale and a 5-point Likert scale. Likert scale is the most effective approach used to measure the level of respondent's perception and opinion based on the statement in questionnaires. The nominal scale is the lowest form of a measurement that uses to simply categorized the respondents' personal information such as age, gender, level of qualification, years of service in the organization, functions, levels of position in the respective organization, and location of work. All the personal variable question that consists of demographic information of respondents will be given in the questionnaires. The initially gather information need to filter out the irrelevant data, in order to have an accurate analysis. Besides, the measurement used for the technology adoption in an organization, employee's job performance level, and perceived job insecurity question is using a 5-point Likert scale to gather data. Respondents will be offered a choice of five-point scale such as Strongly Agree (5), Agree (4), Neutral (3), Disagree (2), and Strongly Disagree (1) that designed to measure the levels of respondent's agreement or disagreement with a particular statement. The gathered data will be further investigated the relationship between technology adoption and employee's job performance.

\section{Instrumentation}

Instrumentation is a process of constructing research instruments that could be used in collecting the data for the study. The most commonly used tools in gathering data for quantitative research is questionnaires or survey. In this research, questionnaires or survey that consists of a series of questions will be used as the research instrument in collecting the specific information of the study from target respondents. The set of questionnaires is described in detail about technology adoption and employee job performance in the Malaysian manufacturing industry while perceived job insecurity as the mediating factor. These survey questionnaires use the online survey as the platform in attaining data effectively while saving time, cost, and ease of distributing throughout the people who are working in the Malaysian manufacturing industry. The questionnaires for this research are adapted from the previous studies. Table 1 below shows the survey questionnaire items such as the research variable and its dimension for this study. 
Table $1 \quad$ Research Test Instruments

\begin{tabular}{lllc} 
Author & Construct & Dimensions & $\begin{array}{c}\text { Number } \\
\text { of Items }\end{array}$ \\
\hline Lee et al (2004) & $\begin{array}{l}\text { Technology } \\
\text { Adoption }\end{array}$ & N/A & 6 \\
Ahmad et al., (2015) & $\begin{array}{l}\text { Employee's Job } \\
\text { Performance }\end{array}$ & $\begin{array}{l}\text { Job Stress } \\
\text { Motivation }\end{array}$ & 6 \\
& Workload & 6 \\
Borg and Elizur & Perceived Job & N/A & 5 \\
(1992) & Insecurity & & 4 \\
& & & \\
\hline
\end{tabular}

\section{Data Analysis and Results}

Research Sample Analysis

In this research, 370 valid responses were used for further analysis after removing all the outliers. All 370 respondents are from the Malaysian Manufacturing Industry.

Table 2 Research Sample Analysis

\begin{tabular}{llcc}
\hline Characteristics & \multicolumn{1}{c}{ Category } & Frequency & (\%) \\
& & & \\
\hline Gender & Male & 289 & 78.1 \\
& Female & 81 & 28.9 \\
Work Experience & 0-5 years & 132 & 35.7 \\
& 6-10 years & 127 & 34.3 \\
& 11-15 years & 29 & 7.8 \\
& 16-20 years & 53 & 14.3 \\
& 21-25 years & 23 & 6.2 \\
& More than 25 & 6 & 1.6 \\
ygears & & \\
& 20-30 years old & 122 & 33.0 \\
& 31-40 years old & 160 & 43.2 \\
& 41-50 years old & 82 & 22.2 \\
& 51-60 years old & 6 & 1.6 \\
& & & \\
\hline
\end{tabular}

Based on Table 2 above, there are total 122 respondents are from age of 20 to 30 years old, 160 respondents are from age of 31 to 40 years old, followed by 82 respondents from age of 41 to 50 years old, and 6 respondents from 51 to 60 years old. For gender, most of the respondent is male 
which have a total of 289 respondents while 81 respondents are female. Other than that, there are 132 respondents having 0-5 working experiences, followed by 127 respondents having 6-10 years working experiences, 29 respondents having 11-15 years, 53 respondents having 16-20 years, 23 respondents having 21-25 years and 6 respondents having working experiences that are more than 25 years.

\section{Research Instruments Reliability}

In order to have good research quality, there are few tests that should be done to ensure the consistency of the result. The reliability of the research survey questionnaires needs to be considered as it reflects the replicability and consistency of results. In this research, the Cronbach coefficient of Alpha ( $\alpha$ ) is used to estimate the reliability, measure the internal consistency of a set of scale or test items and use to calculate the split-half reliability for multiple items. Besides, it also determines the relationship between individual item scores. The components of technology adoption in an organization, employee's job performance, and perceived job insecurity used in this research can be assessed using Cronbach alpha reliability analysis. Before distributing the survey questionnaires to the respondents, a pilot test is needed to be carried to ensure the questionnaires are relevant to the research. The Cronbach $\alpha$ coefficient of reliability ranges from 0 to 1, the pilot test result is said to be consistent and reliable when the coefficient value is said to be higher. For the value of 0.7 and above it illustrates that the internal consistency reliability is satisfactory (DeVellis, 2016). If the $\alpha$ coefficient is less than or equal to 0.7 , it is considered low reliability and unacceptable as it would influence the overall result to be inaccurate. Thus, the reliability issue in this research is fully addressed to best suit the research needs and purpose. A pilot study was conducted by distributing the survey questionnaires to twenty respondents before conducting the main research. This pilot test was done to check the feasibility of the approach before proceeding to a large-scale study. Once the pilot test result suits the purpose of the study, survey questionnaires will be distributed to a large scale of respondents.

Table 3 Research Instrument Reliability

\begin{tabular}{lc}
\hline Construct & $\begin{array}{c}\text { Cronbach's } \\
\text { Alpha }\end{array}$ \\
\hline Technology Adoption & 0.842 \\
Perceived Job Insecurity & 0.889 \\
Employee's Job Performance & 0.718 \\
\hline
\end{tabular}

Based on the pilot test results, all three variables have a Cronbach's alpha that is more than 0.7. According to DeVellis (2016), the $\alpha$ coefficient more than or equal to 0.7 , it is acceptable and can be brought forward to the next process of large-scale distribution throughout the manufacturing industry in Malaysia. 
INTERNATIONAL JOURNAL OF ACADEMIC RESEARCH ECONOMICS AND MANAGEMENT SCIENCES Vol. 9, No. 1, 2020, E-ISSN: 2226-3624 @ 2020 HRMARS

Exploratory Factor Analysis (EFA)

Kaiser-Meyer-Olkin (KMO) is a test that uses to measure the sampling adequacy that examines the appropriateness of the factor analysis. According to Kaiser (1974) and Thompson (2004), the value of $\mathrm{KMO}$ recommends being greater than 0.50 that indicates the sample is adequate. Bartlett's test of Sphericity is used to test for the presences of the null hypothesis that the original correlation matrix has an identity matrix (Hadi, Abdullah, \& Sentosa, 2016). The presence of the null hypothesis can be tested through the significant interrelationship that occurs between variables. The significant value of less than 0.05 is considered appropriate and can proceed for further analysis (Field, 2009).

Table 4 Measure of Sampling Adequacy

KMO and Bartlett's Test

\begin{tabular}{llll}
\hline \multicolumn{4}{c}{ Kaiser-Meyer-Olkin Measure of Sampling Adequacy } \\
Bartlett's Test of & Approx. Chi-Square & \\
Sphericity & & &
\end{tabular}

df 10

Sig. $\quad .000$

Based on Table 4, the KMO value s 0.863 which indicates that the result is adequate. The null hypothesis is rejected as Bartlett's test significant value is 0.000 which is less than 0.05 .

Principle Component Analysis (PCA) is one of the approaches to factor analysis that consider the total variance in the data and transform the original variables into a smaller set of the linear combination. It is the best and well-known approach that is widely used for the dimension reduction technique (Jolliffe, 2011). The purpose of PCA is used to reduce the dimension of the data by searching a few orthogonal linear combinations of the original variables with the largest variance (Fodor, 2002). According to Hair, Black, Babin, Anderson, and Tatham (2006), factor loadings should be greater than 0.5 and anything lesser than the 0.5 is considered a weak relation between variable. 
Table 5 Component Matrix - Technology Adoption

\begin{tabular}{|c|c|c|}
\hline Construct & Items & $\begin{array}{l}\text { Factor } \\
\text { Loading }\end{array}$ \\
\hline Technology & TA1. & \\
\hline \multirow[t]{8}{*}{ Adoption } & $\begin{array}{l}\text { y organization provides technology support } \\
\text { for collaborative work regardless of time } \\
\text { and place. } \\
\text { TA2. }\end{array}$ & 0.750 \\
\hline & $\begin{array}{l}\text { y organization provided technology support } \\
\text { for communication among organization } \\
\text { members. }\end{array}$ & 0.800 \\
\hline & TA3. & \\
\hline & $\begin{array}{l}\text { y organization provides technology support } \\
\text { for searching and accessing necessary } \\
\text { information. }\end{array}$ & 0.800 \\
\hline & TA4. & \\
\hline & $\begin{array}{l}\text { y organization provides technology support } \\
\text { for simulation and prediction. }\end{array}$ & 0.806 \\
\hline & TA5. & \\
\hline & $\begin{array}{l}\text { y organization provides technology for } \\
\text { systematic storing. }\end{array}$ & 0.796 \\
\hline
\end{tabular}

Based on Table 5, the factor analysis for technology adoption variables can be concluded that all the 5 items having strong factor loadings.

Table 6 Rotated Component Matrix - Employee Job Performance

\begin{tabular}{llc} 
Construct & Items & $\begin{array}{c}\text { Factor } \\
\text { Loading }\end{array}$ \\
\hline Job Stress & $\begin{array}{l}\text { JS1. } \\
\text { feel that working closely with technology } \\
\text { cause a great deal of tension. }\end{array}$ & 0.771 \\
& JS2. & 0.825 \\
& feel technology frustrates me. & \\
& JS3. & 0.743 \\
& consider leaving technology & \\
& JS4. & 0.791 \\
& feel that I work too hard in technology. & \\
& JS5. & 0.801 \\
& feel that working with technology leads to \\
& burnout. &
\end{tabular}


INTERNATIONAL JOURNAL OF ACADEMIC RESEARCH ECONOMICS AND MANAGEMENT SCIENCES Vol. 9, No. 1, 2020, E-ISSN: 2226-3624 @ 2020 HRMARS

\begin{tabular}{|c|c|c|}
\hline Construct & Items & $\begin{array}{l}\text { Factor } \\
\text { Loading }\end{array}$ \\
\hline \multirow[t]{9}{*}{ Motivation } & M01. & \\
\hline & $\begin{array}{l}\text { hen I use technology to complete my job, I } \\
\text { feel a sense of personal satisfaction }\end{array}$ & 0.777 \\
\hline & $\begin{array}{l}\text { MO2. } \\
\text { take pride in doing my job as well as I can. } \\
\text { MO3. }\end{array}$ & 0.878 \\
\hline & $\begin{array}{l}\text { feel unhappy when my work is not up to my } \\
\text { standard when I use technology. }\end{array}$ & 0.885 \\
\hline & $\begin{array}{l}\text { MO4. } \\
\text { feel satisfied when I sense the job of the } \\
\text { day is well done. }\end{array}$ & 0.792 \\
\hline & MO5. & \\
\hline & $\begin{array}{l}\text { try to think of using technology to do my } \\
\text { job effectively. }\end{array}$ & 0.566 \\
\hline & Mo6. & \\
\hline & $\begin{array}{l}\text { hen I use technology to complete my job, I } \\
\text { feel a sense of personal satisfaction }\end{array}$ & 0.600 \\
\hline \multirow[t]{4}{*}{ Workload } & WL1. & \\
\hline & $\begin{array}{l}\text { ue to technology, my workload affecting my } \\
\text { working capabilities. }\end{array}$ & 0.716 \\
\hline & WL2. & \\
\hline & $\begin{array}{l}\text { ue to technology, my workload affecting my } \\
\text { personal life. }\end{array}$ & 0.708 \\
\hline
\end{tabular}

Based on Table 6, the factor analysis for employee's job performance variables can be concluded that all 3 dimensions are related and can be used in the hypothesis analysis. However, there are a total of 5 items known as JS6, MO2, WL1, WL4, WL5 are overlapping into another dimension which has been removed for further analysis. 
Table 7 Component Matrix - Perceived Job Insecurity

\begin{tabular}{llc} 
Construct & Items & $\begin{array}{c}\text { Factor } \\
\text { Loading }\end{array}$ \\
\hline $\begin{array}{l}\text { Perceived Job } \\
\text { Insecurity }\end{array}$ & $\begin{array}{l}\text { PJI1. } \\
\text { believe that my job in this organization is } \\
\text { secure. }\end{array}$ & 0.879 \\
& PJI2. & \\
& n my opinion, I will have a job in this \\
& organization for as long as I want one. & \\
& PJI3. \\
& $\begin{array}{l}\text { am confident that this organization will } \\
\text { continue to need my skills and job }\end{array}$ & \\
& knowledge. \\
& $\begin{array}{l}\text { PJI4. } \\
\text { y job performance history will protect me } \\
\text { from losing my job in this organization. }\end{array}$ & \\
&
\end{tabular}

Based on Table 7, the factor analysis for the perceived job insecurity variable concludes that all 4 items have met required threshold levels of factor loading and therefore can be used for hypothesis testing.

\section{Hypotheses Testing}

Hypothesis testing is a statistical technique that is used in making the statistical decision by using the observation data. The purpose of hypothesis testing is to prove whether the developed hypothesis is true or false. This determines the outcome of the study. In hypothesis testing, the significant $p$-value is used to determine the significance of the result either support or reject. The hypothesis with a significant $p$-value that is less than 0.05 , which indicates that the hypothesis is significant and supported. A t-value is a standardized value that is calculated the size of the difference relative to the variation from the sample data during a hypothesis test. The closer the $\mathrm{t}$-value to 0 , the more likely the hypothesis is not significant. The standardized beta coefficient is used to compares the strength of the effect of each individual dependent variable and independent variable. The higher the value of the standardized beta coefficient, the stronger the effect. The sign in the standardized beta coefficient indicates it is a positive relationship or negative relationship between the dependent variable and the independent variable. 
The results of path coefficients are shown in Table 8.

Table 8 Standardized Regression Weights Based on Fit Model

\begin{tabular}{|c|c|c|c|c|c|c|c|}
\hline Hypothesis & $\begin{array}{c}\text { Endogeno } \\
\text { us }\end{array}$ & & xogenous & $\begin{array}{c}\text { Std. } \\
\text { Estima } \\
\text { te }\end{array}$ & $\begin{array}{c}t- \\
\text { value }\end{array}$ & P-Value & $\begin{array}{c}\text { Decision at } \\
p<0.05\end{array}$ \\
\hline $\mathrm{H} 1 \mathrm{a}$ & JS & $\leftarrow$ & TA & -0.264 & -5.250 & 0.000 & Significant \\
\hline $\mathrm{H} 1 \mathrm{~b}$ & MO & $\leftarrow$ & TA & 0.327 & 6.633 & 0.000 & Significant \\
\hline $\mathrm{H} 1 \mathrm{C}$ & WL & $\leftarrow$ & TA & -0.041 & -0.789 & 0.431 & Insignificant \\
\hline
\end{tabular}

Based on Table 8 , the $t$-value is -5.250 while the $p$-value is $0.000<0.050$. This result indicates that hypothesis, $\mathrm{H} 1 \mathrm{a}$ is supported and a significant relationship is found between technology adoption and job stress. The standardized beta value of -0.264 shows that there is the support that technology adoption influences employee's job stress, the negative standardized beta indicates that there is a negative relationship. As a result, a negative relationship exists between technology adoption and job stress. In testing motivation, the t-value is 6.633 while the $p$-value is $0.000<0.050$. This result indicates that hypothesis, $\mathrm{H} 1 \mathrm{~b}$ is supported and a significant relationship is found between technology adoption and motivation. The standardized beta value of -0.327 shows that there is support that technology adoption influences employee's motivation. As a result, there is a relationship exist between technology adoption and motivation. The $t$-value for workload is -0.789 while the $p$-value is $0.431>0.050$. This result indicates that hypothesis, $\mathrm{H} 1 \mathrm{c}$ is not supported and no significant relationship is found between technology adoption and workload. The standardized beta value of -0.041 shows that there is no support that technology adoption influences an employee's workload. As a result, there is no relationship exist between technology adoption and workload.

Mediating hypotheses testing is used to investigate the effect of the mediator on the relationship between the dependent variable and the independent variable. Baron and Kenny (1986) proposed a method for testing the relationship of two variables, independent variable and dependent variable with a mediating factor. It suggested the four-step approach of regression analysis to determine the significance of the coefficients derived at each step. The first three steps are to identify that there is a zero-order relationship among the tested variables. Once all three-step indicate a significant relationship between two variables and mediating factor, step four can proceed. According to MacKinnon, Fairchild, and Fritz (2007), mediation does not occur if one of the steps from the first three-step having an insignificant relationship. For step 4, partial mediation is supported if the mediating factor perceived job insecurity remains significant after controlling the independent variable, technology adoption. 
INTERNATIONAL JOURNAL OF ACADEMIC RESEARCH ECONOMICS AND MANAGEMENT SCIENCES Vol. 9, No. 1, 2020, E-ISSN: 2226-3624 @ 2020 HRMARS

Table 9 Mediation Analysis

\begin{tabular}{cccccccc}
\hline & \multicolumn{8}{c}{$\begin{array}{c}\text { Std. } \\
\text { Step }\end{array}$} & $\begin{array}{c}\text { Endogeno } \\
\text { us }\end{array}$ & \multicolumn{8}{c}{$\begin{array}{c}\text { Exogenous Estima } \\
\text { te }\end{array}$} & $\begin{array}{c}\text { value } \\
\text { Decision at }\end{array}$ \\
\hline 1 & EJP & $\leftarrow$ & TA & -0.060 & -1.152 & 0.250 & Insignificant \\
2 & PJI & $\leftarrow$ & TA & 0.205 & 4.022 & 0.000 & Significant \\
3 & EJP & $\leftarrow$ & PJI & -0.249 & -4.935 & 0.000 & Significant \\
4 & EJP & $\leftarrow$ & TA \& PJI & - & - & - & \\
& & & & - & - & - & \\
\hline
\end{tabular}

Based on Table 9, the first step shows the significant p-value of $0.250>0.050$ which indicates that the independent variable, employee's job performance is not significantly affecting the dependent variable in the absence of the mediator. For step 2 and 3 shows the significant $p$-value $0.000<0.050$ which indicates that the independent variable is significant to affect the mediator and the mediator has a significant effect on the dependent variable. Since step 1 indicates no significant relationship between two variables, it is not allowed to continue with step 4 . As a result, no mediation exists between the two variables.

\section{Discussion}

Employee's job performance consists of three dimensions which include job stress, motivation, and workload. As stated by Dauda (2011), the organization who tend to lay emphasize on capital in term of technology advancements such as machinery and equipment tend to reduce labor cost in order to increase their profitability. It does not increase the employee's productivity and performance. The substitution of the technology for labor does not really signify employee's performance and productivity. According to Wanza and Nkuraru (2016), constructing and reconstructing existing technology in an organization to cater to customer needs and market change gives an unsatisfying outcome. This is proven that half of these technologies change project experiences failure and does not improve employee's performance. In the Malaysian manufacturing sector, a total of 49,101 companies had established in the year 2015 and 47,698 (97.1\%) are from Small to Medium Enterprise (SME) while others are from large firms (Department of Statistics Malaysia, 2016). Based on the Federation of Malaysian Manufacturers (FMM), the readiness of the Malaysian manufacturing industry in adopting advanced technology such as automation is very low. Most of the SME companies are aware of the need to embrace industry 4.0 but they have not seriously adopted automation technology in their companies. This is mainly due to the initial cost of automating and digitizing their business could be a big challenge for them and they are lacking relevant talents to lead them forward in these developments. This contrary to many findings on the impact of technology on the organization and employee performance has been explained that the capacity to adopt the acquire technology advancement may be low in the Malaysian manufacturing industry.

According to Korunka et al (1993) and Karsh (2004), employee involvement in the implementation of new technology decision leads to a higher level of acceptance of the new technologies and reduce job dissatisfaction as well as reduce the level of stress. According to David (2003), there are many factors that influence an individual's attitudes which can motivate 
an individual to accept and move towards new technologies. He mentioned that motivated employees tend to embrace the changes and seek new applications for technology advancement. Based on Bhaduri and Kumar (2011), motivated employees tend to become an adopter of technology changes when the employee desired to acquire relative skills and knowledge to support the organizational goal. As stated by Kwon Choi, Koo Moon, and Ko (2013) and Plewa, Troshani, Francis, and Rampersad (2012), the researchers confirmed that adoption of technology in an organization is an important factor for moderating employee's motivation and achieving organizational performances and effectiveness. This strengthens the relationship between technology adoption and motivation. According to Suharti and Susanto (2014), employee's workload increases when involved in a high-tech work environment. This is because they required to learn and master high-tech skills and knowledge. Based on Pires, Matos, Azambuja, Trindade, and Scherer (2014), employee's workload increases when they are required to adopt new technology and have to learn how to manage the equipment and organization. These authors also mentioned that providing education and training to employees contributes to increased confidence and security in handling the new technology which could eventually reduce their workloads. Most of the research shows that there is a significant relationship between technology adoption and workload. However, limited research shows no significant relationship. According to Abramis (1994), employee decrease in performance and plan to leave the job is assumed to be a consequence of perceived job insecurity. Other than that, De Witte (2005) also mentioned perceived job insecurity is associated with employee performance decrease and reduce organizational citizenship behaviors. The result also shows that there is a significant relationship between technology adoption and perceived job insecurity. As stated by Gallivan (2004) and Benamati and Lederer (2001), the fast pace of technological change in an organization increase the need to acquire more skills and knowledge to perform according to the latest technological change. The pressure of continuously enhancing the skills and knowledge to perform efficiently to technology advancement is creating more pressure and insecurity among the employees. Due to no significant relationship between technology adoption and employee job performance, therefore there is no mediating effect of perceived job security.

\section{Conclusion}

The present research explores and identifies the relationship between technology adoption and employee job performance as well as determining the mediating effect of perceived job insecurity in the Malaysian manufacturing industry. The finding obtained from this study has shown that two out of three factors contributing to employee's job performance such as job stress and motivation have a significant relationship with technology adoption. One of the factors for employee job performance, the workload does not have a significant relationship with technology adoption. The mediating effect of perceived job insecurity has no significant relationship between technology adoption and employee job performance. This study has offered some theoretical and practical contributions.

In terms of theoretical contribution, this study contributed to provide clear information on Malaysia's employee's job performance when adoption technology in a manufacturing company. This research gives further insight into the factors contributing to employee's job performance such as job stress, motivation, and workload which will influence by the technology adoption of an organization. Besides that, it also provides the researchers with a better understanding of the 
linkage of technology adoption with employee's job performance. These relationships were tested and additional information pertaining to technology adoption and employee's job performance has been developed from the findings. Moreover, the negative results on perceived job insecurity as a mediator effect on technology adoption and employee's job performance give information to the researcher this mediator factor is not influencing both variables. Other than that, the field of study is new as it only covers on Malaysian manufacturing industry, it can be used as a reference for future researches whose study is related to this field. Lastly, the results of this study could be used to develop a new theoretical framework in future researches.

In terms of managerial contribution, the findings from this study could be used by all manufacturing industries as they are focusing on technology adaption in order to sustain their position in the market and being more productive. It will give the manufacturing industry an insight into technology development influencing an individual's performance at work. According to Davis (1989), the attitude-behavior of individual influences an individual to adopt or reject technology. This is a very important aspect as the employee's performance directly portraits through their behavior. Besides that, the manufacturing industry can utilize the data from this study in their research and development to secure jobs in spite of technology adoption to ensure that the employee's job performance remains at peak. This study is also beneficial to the government sector as it also helps them to understand the need for technology in attaining good job performance. The study can also help in understanding the effects of job stress, workload, and motivation influencing the job performance of an individual.

\section{References}

Abramis, D. J. (1994). Relationship of job stressors to job performance: Linear or an inverted-U?. Psychological Reports, Vol. 75(1), pp. 547-558.

Achieng, D. O., \& Jagero, J. A. (2014). Management Support in Adoption of Computer Integrated Model in Financial Forecasting. International Journal of Academic Research in Accounting, Finance and Management Sciences, Vol. 4(2), pp. 170-179.

Ahmad, S. (2014). Technology in organizations. International Journal of Research in Business Management, Vol. 2(7), pp. 73-80.

Ahmad, A., Khan, M. U., Srikanth, A. B., Patel, I., Nagappa, A. N., \& Jamshed, S. Q. (2015). Evaluation of workload and its impact on satisfaction among pharmacy academicians in Southern India. Journal of Clinical and Diagnostic Research, Vol. 9(6), FC01.

Ajzen, I. (1991). The theory of planned behavior. Organizational Behavior and Human Decision Processes, Vol. 50(2), pp. 179-211.

Ammar, T. (2006). The effect of internal variables on the level of job stress on the employees of Palestinian Universities at Gaza Strip. Master thesis. Islamic University, Gaza, 55.

Al-Aulamie, A. (2013) 'Enhanced technology acceptance model to explain and predict learners' behavioural intentions in learning management systems'. Ph.D. thesis. University of Bedfordshire.

Ali, W., Raheem, A., Nawaz, A., \& Imamuddin, K. (2014). Impact of stress on job performance: An empirical study of the employees of Private Sector Universities of Karachi, Pakistan. International Science Congress Association, Vol. 3(7), pp. 14-17. 
Awan, W. A., \& Salam, A. (2014). Identifying the relationship between job insecurity and employee performance-An evidence from private colleges in Larkana, Pakistan. Beykent University Journal of Social Sciences, Vol. 7(1), pp. 23-30.

Bagozzi, R. P. (2007). The legacy of the technology acceptance model and a proposal for a paradigm shift. Journal of the Association for Information Systems, Vol. 8(4), pp. 244-254.

Benamati, J., \& Lederer, A. L. (2001). Coping with rapid changes in IT. Communications of the ACM, Vol. 44(8), pp. 83-88.

Bernerth, J. (2004). Expanding our understanding of the change message. Human Resource Development Review, Vol. 3(1), pp. 36-52.

Bhaduri, S., \& Kumar, H. (2011). Extrinsic and intrinsic motivations to innovate: tracing the motivation of 'grassroot' innovators in India. Mind \& Society, Vol. 10(1), pp. 27-55.

Borman, W. C., \& Motowidlo, S. M. (1993). Expanding the Criterion Domain to Include Elements of Contextual Performance, in N. Schmitt \& W. C. Borman (Eds.), Personnel Selection in Organizations, p. 71-98.

Borg, I., \& Elizur, D. (1992). Job insecurity: Correlates, moderators and measurement. International Journal of Manpower, Vol. 13(2), pp. 13-26.

Campbell, D., \& Sengenberger W. (1994). Labour standards, economic efficiency and development: lessons from experience with industrial restructuring. International Institute for Labor Studies, Vol. 49(2), pp. 421-39.

Chuan, C. L. (2006). Sample size estimation using Krejcie and Morgan and Cohen statistical power analysis: A comparison. Jurnal Penyelidikan IPBL, Vol. 7(1), pp. 78-86.

Conway, P. M., Campanini, P., Sartori, S., Dotti, R., \& Costa, G. (2008). Main and interactive effects of shift work, age and work stress on health in an Italian sample of healthcare workers. Applied Ergonomics, Vol. 39(5), pp. 630-639.

Conley, S., \& Woosley, S. A. (2000), Teacher role stress, higher order needs and work outcomes. Journal of Educational Administration, Vol. 38(2), pp. 179-201.

Davis, F. D. (1989). Perceived usefulness, perceived ease of use, and user acceptance of information technology. MIS Quarterly, Vol. 13(3) pp. 319-340.

Dauda, Y. A., \& Akingbade, W. A. (2011). Technology innovation and Nigeria banks performance: The assessment of employee's and customer's responses. American Journal of Social and Management Sciences, Vol. 2(3), pp. 329-340.

DeCenzo, D. A., \& Robbins, S. P. (1996). Human resources management. New York: John Wiley \& Sons, Inc.

DeVellis, R. F. (2016). Scale development: Theory and applications. Sage Publications.

De Witte, H. (2005). Job insecurity: Review of the international literature on definitions, prevalence, antecedents and consequences. SA Journal of Industrial Psychology, Vol. 31(4), pp. 1-6.

Ekerman, G. (2006). Job Enrichment and Staff Motivation. Human Resource Management (pp. 183-191). Cape Town: Maskew Miller Longman (Pvt) Ltd.

Field, A. (2009). Discovering Statistics Using SPSS: Introducing Statistical Method (3rd edition). Sage Publications.

French, Jr. J. R. (1975). A comparative look at stress and strain in policemen. Job stress and the police officer: Identifying stress reduction techniques. Proceedings of Symposium, $\mathrm{WH}$ Kroes, J J Hurrell, Jr - See Ncj-43642. 
Fodor, I. K. (2002). A survey of dimension reduction techniques. Center for Applied Scientific Computing, Lawrence Livermore National Laboratory, Vol. 9, pp.1-18.

Gallivan, M. J. (2004). Examining IT professionals' adaptation to technological change: the influence of gender and personal attributes. ACM SIGMIS Database: the DATABASE for Advances in Information Systems, Vol. 35(3), pp. 28-49.

George, J. M., Jones, G. R., \& Sharbrough, W. C. (2002). Understanding and managing organizational behavior. Prentice-Hall, Upper Saddle River.

Giancola, F. L. (2014). Should HR Professionals Devote More Time to Intrinsic Rewards?. Compensation \& Benefits Review, Vol. 46(1), pp. 25-31.

Hadi, N. U., Abdullah, N., \& Sentosa, I. (2016). An Easy Approach to Exploratory Factor Analysis: Marketing Perspective. Journal of Educational and Social Research, Vol. 6(1), pp. 215-224.

Hair, J. F, Black, W. C., Babin, B. J., Anderson, R. E., \& Tatham, R. E. (2006). Multivariate data analysis (6th edition). Upper Saddle River, New Jersey: Prentice-Hall.

Hampel, P. S., \& Martinsons, M. G. (2009). Developing international organizational change theory using cases from China. Human Relations, Vol. 62(4), pp. 459-499.

Han, S. (2003). Individual adoption of information systems in organizations: A literature review of technology acceptance model. Technical Report 540, Turku Centre for Computer Science.

Hellgren, J., \& Sverke, M. (2003). Does job insecurity lead to impaired well-being or vice versa? Estimation of cross-lagged effects using latent variable modelling. Journal of Organizational Behavior, Vol. 24(2), pp. 215-236.

Ho-Jin, P., \& Cho, J. S. (2016). The influence of information security technostress on the job satisfaction of employees. Journal of Business and Retail Management Research, Vol. 11(1)., pp. 66-75.

Hsieh, H-L., Huang, L-C., \& Su, K-J. (2004). Work stress and job performance in the hi tech industry: A closer view for vocational education. World Transactions on Engineering and Technology Education, 3(1), pp.147-150.

Ibrahim, N. A. (2013). The Effects of Worker Stress on the Job Performance in Electronic Manufacturing. Doctoral dissertation, UMP.

Idris, M. (2011). Over time effects of role stress on psychological strain among Malaysian Public University Academics. International Journal of Business and Social Science, Vol. 4(1), pp. 44-48.

Im, M., \& Han, G. (2013). An investigation of causes and effects of technostress creators, The Journal of Digital Policy \& Management, Vol. 11(10), pp.31-45.

Imran, M., Maqbool, N., \& Shafique, H. (2014). Impact of technological advancement on employee performance in banking sector. International Journal of Human Resource Studies, Vol 4(1), pp. 57.

Jolliffe, I. (2011). Principal component analysis. In International Encyclopedia of Statistical Science, pp. 1094-1096. Springer, Berlin, Heidelberg

Kahya, E. (2009). The effects of job performance on effectiveness. International Journal of Industrial Ergonomics, Vol. 39(1), pp. 96-104.

Kaiser, H. F. (1974). An index of factorial simplicity. Psychometrika, Vol. 39(1), pp. 31-36.

Karsh, B. T. (2004). Beyond usability: designing effective technology implementation systems to promote patient safety. BMJ Quality \& Safety, Vol. 13(5), pp. 388-394. 
Klug, K. (2017). Young and at risk? Consequences of job insecurity for mental health and satisfaction among labor market entrants with different levels of education. Economic and Industrial Democracy, Vol. 27(2), pp. 223-244.

Korunka, C., Weiss, A., \& Karetta, B. (1993). Effects of new technologies with special regard for the implementation process per se. Journal of Organizational Behavior, Vol. 14(4), pp. 331-348.

Krejcie, R. V., \& Morgan, D. W. (1970). Determining sample size for research activities. Educational and Psychological Measurement, Vol. 30(3), pp. 607-610.

Choi, K. B., Moon, K. H., \& Ko, W. (2013). An organization's ethical climate, innovation, and performance: Effects of support for innovation and performance evaluation. Management Decision, Vol. 51(6), pp. 1250-1275.

Kwon, O., \& Wen, Y. (2010). An empirical study of the factors affecting social network service use. Computers in Human Behavior, Vol. 26(2), pp. 254-263.

Lee, C. P., Warkentin, M., \& Choi, H. (2004). The role of technological and social factors on the adoption of mobile payment technologies. AMCIS 2004 Proceedings, 333.

Lee, Y., Kozar, K. A., \& Larsen, K. R. T. (2003). The technology acceptance model: past, present, and future. Communications of the AIS, Vol. 12(50), pp. 752-80.

Legris, P., Ingham, J., \& Collerette, P. (2003). Why do people use information technology? A critical review of the Technology Acceptance Model. Information \& Management, Vol. 40(3), pp. 191-204.

Lin, H. F. (2007). Effects of extrinsic and intrinsic motivation on employee knowledge sharing intentions. Journal of Information Science, Vol. 33(2), pp. 135-149.

Nasri, W., \& Charfeddine, L. (2012). Motivating salespeople to contribute to marketing intelligence activities: An expectancy theory approach. International Journal of Marketing Studies, Vol. 4(1), pp. 168.

Madsen, S. R., Miller, D., \& John, C. R. (2005). Readiness for organizational change: do organizational commitment and social relationships in the workplace make a difference. Human Resource Development Quarterly, Vol.1(2), pp. 213-33.

Mizuno, M., Yamada, Y., Ishii, A., \& Tanaka, S. (2006). A human resource management approach to motivation and job stress in paramedics. In International Congress Series, Vol. 1294, pp. 167-170.

Muda, I., Rafiki, A., \& Harahap, M. R. (2014). Factors influencing employees' performance: A study on the Islamic banks in Indonesia. International Journal of Business and Social Science, Vol. 5(2), pp. 73-80.

Meuter, M. L., Ostrom, A. L., Roundtree, R. I., \& Bitner, M. J. (2000). Self-service technologies: understanding customer satisfaction with technology-based service encounters. Journal of Marketing, Vol. 64(3), pp. 50-64.

Motowidlo, S., Borman, W., \& Schmidt, N. (1997). A theory of individual differences in task and contextual performance. Human Performance, Vol. 10, pp. 71-83.

Odeh, M. H. (2019). Factors Affecting the Adoption of Financial Information Systems Based on UTAUT Model. International Journal of Academic Research in Accounting, Finance and Management Sciences, Vol. 9(2), pp. 108-116. 
Pantano, E., \& Di Pietro, L. (2012). Understanding consumer's acceptance of technology-based innovations in retailing. Journal of technology management \& innovation, Vol. 7(4), pp. 1-19.

Parashar, B. K. (2016). Significance of theory Z in Indian scenario. International Journal of Management and Social Sciences Research, Vol. 5(2), pp. 8-16.

Park, C., \& Im, M. (2012). The impact of technostress on information security perception and organizational outcomes, The Journal of KIIT, Vol. 10(1), pp. 97-109.

Plewa, C., Troshani, I., Francis, A., \& Rampersad, G. (2012). Technology adoption and performance impact in innovation domains. Industrial Management \& Data Systems, Vol. 112(5), pp. 748-765.

Pires, D. E. P. D., Matos, E., Azambuja, E. P. D., Trindade, L. D. L., \& Scherer, M. D. D. A. (2014). New Technologies and Workloads of Health Care Professionals. Universitätsverlag der TU Berlin.

Poissonnet, C. M., \& Véron, M. (2000). Health effects of work schedules in healthcare professions. Journal of Clinical Nursing, Vol. 9(1), pp. 13-23.

Rizwan, M., Waseem, A., \& Bukhari, S. A. (2014). Antecedents of job stress and its impact on job performance and job satisfaction. International Journal of Learning and Development, Vol. 4(2), pp.187-203.

Saeed, R., Mussawar, S., Lodhi, R. N., Iqbal, A., Nayab, H. H., \& Yaseen, S. (2013). Factors affecting the performance of employees at work place in the banking sector of Pakistan. MiddleEast Journal of Scientific Research, Vol. 17(9), pp. 1200-1208.

Schultz, R. L., \& Slevin, D. P. (1975). Implementation and Organizational Validity: An Empirical Investigation. In Implementing Operations Research Management Science, R.L. Schultz and D.P. Slevin (eds.), American Elsevier, New York, NY, pp. 153-182.

Suharti, L., \& Susanto, A. (2014). The impact of workload and technology competence on technostress and performance of employees. Indian Journal of Commerce and Management Studies, Vol. 5(2), pp. 1.

Surendran, P. (2012). Technology acceptance model: A survey of literature. International Journal of Business and Social Research, Vol. 2(4), pp. 175-178.

Sverke, M., \& Goslinga, S. (2003). The consequences of job insecurity for employers and unions: Exit, voice and loyalty. Economic and Industrial Democracy, Vol. 24(2), pp. 241-270.

Swanson, E. B. (1982). Measuring user attitudes in MIS research: a review. Omega, Vol. 10(2), pp. 157-165.

Talukder, M. (2012). Factors affecting the adoption of technological innovation by individual employees: An Australian study. Procedia-Social and Behavioral Sciences, Vol. 40, pp. 5257.

Thompson, B. (2004). Exploratory and confirmatory factor analysis: Understanding concepts and applications. Applied Psychological Measurement, Vol. 31(3), pp. 245-248.

Tornatzky, L. G., \& Klein, K. J. (1982). Innovation characteristics and innovation adoptionimplementation: A meta-analysis of findings. IEEE Transactions on Engineering Management, Vol. 29(1), pp. 28-45.

Van Scotter, J. R., \& Motowidlo, S. J. (1996). Interpersonal facilitation and job dedication as separate facets of contextual performance. Journal of Applied Psychology, Vol. 81(5), pp. 525. 
Elst, V. T., De Witte, H., \& De Cuyper, N. (2014). The Job Insecurity Scale: A psychometric evaluation across five European countries. European Journal of Work and Organizational Psychology, Vol. 23(3), pp. 364-380.

Vieitez, J. C., Carcía, A. D. L. T., \& Rodríguez, M. T. V. (2001). Perception of job security in a process of technological change: Its influence on psychological well-being. Behaviour \& Information Technology, Vol. 20(3), pp. 213-223.

Wanza, S. L., \& Nkuraru, J. K. (2016). Influence of Change Management on Employee Performance: A Case of University of Eldoret, Kenya. International Journal of Business and Social Science, Vol. 7(4), pp. 190-199.

Werner, J. M. (2000). Implications of OCB and contextual performance for human resource management. Human Resource Management Review, Vol. 10(1), pp. 3-24.

Witt, L. A., Kacmar, K. M., Carlson, D. S., \& Zivnuska, S. (2002). Interactive effects of personality and organizational politics on contextual performance. Journal of Organizational Behavior, Vol. 23(8), pp. 911-926.

Yousafzai, S. Y., Foxall, G. R., \& Pallister, J. G. (2007). Technology acceptance: a meta-analysis of the TAM: Part 1, Journal of Modelling in Management, Vol. 2(3), pp. 251-280.

Yusoff, W. T. W., Mat, C. R. C., \& Zainol, R. M. (2017). Predictors and consequences of job insecurity: A preliminary study of Malaysian bank employees. Geografia-Malaysian Journal of Society and Space, Vol. 10(3), pp. 8-13

Zafar, Q., Ali, A., Hameed, T., Ilyas, T., \& Younas, H. (2015). The Influence of Job Stress on Employees Performance in Pakistan. American Journal of Social Science Research, Vol. 1(4), pp. 221-225. 